\title{
FAMILY HOUSE COURTYARD IN THE CONTEXT OF SUSTAINABLE ARRANGEMENT
}

\author{
Amorino Poropat
}

Original scientific paper This article is a contribution of technical sciences to the terms of spatial planning and sustainable building and landscape arrangements of a family house courtyard. The methods of analysis, synthesis, as well as the empirical method were applied, resulting in this scientific research. A random sample was chosen to determine the dimension of landscape plans for the rear part of a courtyard and its dimensions are compared to the optimal dimensions of the landscape elements of traffic access and leisure area for the purposes of their sustainable arrangements. A method of detection of unfavourable positions of plants in the courtyard has been discovered and their relocation and treatment for normal and sustainable growth. The determined contents and ratio between the building and landscape arrangements of a family house courtyard are the interest and the will of the owner to choose and realise possible terms within the surface area of his courtyard.

Keywords: building arrangements; family house courtyard; landscaping

Okućnica obiteljske kuće u načinu održivog uređenja

Izvorni znanstveni članak Ovaj članak je doprinos tehničkih znanosti u pojmovima prostornog planiranja i održivom građevnom i biljnom uređenju okućnice obiteljske kuće. Primijenjena je metoda analize, sinteze i empirije, a rezultati su znanstvena istraživanja naslovne teme. Odabran je slučajni uzorak za utvrđivanje veličine pejzažnih planova sa stražnjeg dijela okućnice, a njegove veličine su uspoređene sa optimalnim veličinama elemenata uređenja prometnog pristupa i odmora, radi njihova održiva uređenja. Otkriven je način detekcije nepovoljnog položaja biljaka na okućnici i njihovo izmicanje i tretman za pravilan i održivi rast. Utvrđeni sadržaji i odnosi građevnog i biljnog uređenja okućnice obiteljske kuće su interes i volja vlasnika za izbor i realizaciju mogućih pojmova unutar površine pripadajuće okućnice.

Ključneriječi: biljno uređenje; građevno uređenje; okućnica obiteljske kuće

\section{Introduction}

In spatial planning, courtyard is the feature of allocation for an unbuilt portion of the building or construction plot. Courtyard in the cadastral plan is the feature of the way in which the unbuilt portion of the cadastral plot (building) is exploited. In Croatia, the synonyms for courtyard are: yard (applied in land register), garden (applied in architecture), whereas from the legal aspect, courtyard is the property of land. The way in which the courtyard will be arranged and maintained is left to the will of the owner or its users. The users are family members or occupants and, in some cases, lease holders or tenants. The aforementioned users' wills differ from case to case. Some users themselves take care of their courtyards partially, fully or not at all, while others arrange their courtyards in a planned manner, based on a landscape plan, prepared by a landscape or authorised architect. In some cases, maintenance of courtyards is left to individuals or companies competent in horticultural arrangement, at an appropriate cost. In Croatia, courtyard arrangement in part depends on the execution of works for building infrastructural connections, which are carried out under the ground, in trenches or canals, most frequently partially and not simultaneously, so, time-wise, their execution (excavation, laying of lines or pipes, shafts, cover lids and back filling) spreads over many years. Eventually, streets and access roads to the family house courtyards are partially and, more rarely, fully communally and infrastructurally equipped with connections to the electricity, water and drainage mains, telephone, gas, especially public lighting and, in some areas, also public parking. In the course of installation of the said connections, courtyard arrangements also include the arrangement of the ground, which can be a soft soil base, a humus soil base, a lawn or a firm soil base: macadam, concrete, asphalt or tiles, as a part of the construction arrangement. Most recently, the structural rules for optimal dimensions of four family house plot elements have been scientifically determined (Fig. 1).

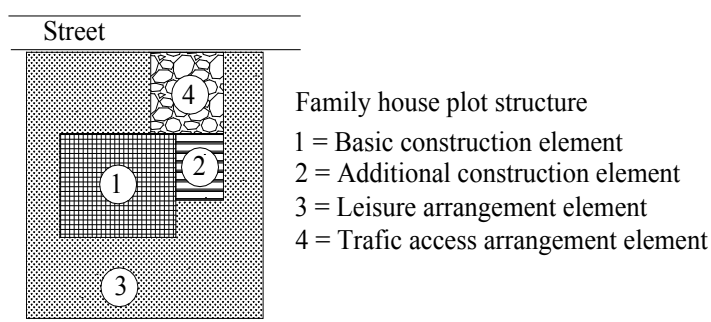

Figure 1 Courtyard with elements of arrangements for leisure (3) and traffic access (4)[1,2] - correction of element terms

The equation for optimisation of the elements of a family house plot in Istria is determined $[1,2]$.

$$
\begin{aligned}
& A_{2}=A_{\mathrm{a}}+A_{\mathrm{b}}+A_{\mathrm{c}}+A_{\mathrm{d}}= \\
& =\left(34 \% \cdot A_{2}\right)+\left(10 \% A_{2}\right)+\left(49 \% \cdot A_{2}\right)+\left(7 \% A_{2}\right)
\end{aligned}
$$

where: $A_{2}=$ Building plot surface area $\left(\mathrm{m}^{2}\right) ; A_{\mathrm{a}}=$ Optimal surface area of elements of basic construction $(115 \div 246)$ $\mathrm{m}^{2} ; A_{\mathrm{b}}=$ Optimal surface area of additional construction $(31 \div 71) \mathrm{m}^{2} ; A_{\mathrm{c}}=$ Optimal surface area of elements of leisure arrangement: $(45 \div 286) \mathrm{m}^{2} ; A_{\mathrm{d}}=$ Optimal surface area of traffic access arrangement elements: $(8 \div 48) \mathrm{m}^{2}$.

Optimal building plot dimensions are not equal and, using the Eq. (1), they are averaged and balanced in the proportion of their ratios. The application of optimal dimensions in the ratio between elements arrangement of leisure and traffic access is one of the measures which can 
consolidate or maintain the courtyard size for quality life of its users. Research on a family house plot in Istria [3, 4] shows that, in time, the surface area of the courtyard reduces due to the expansion or extension of the house. One of the reasons for extensions is the increase in residential units for rental and additional income purposes. In Croatia, the method of sustainable courtyard arrangement was not legalised or scientifically determined until the year 2015. The problem is the sustainability of arrangement in the size of the courtyard. By reduction of the courtyard size below the optimal dimensions or ratio disturbance at the level of its elements of arrangement for leisure and traffic access, the user's psychophysical wellbeing is also reduced. The psychophysical fitness includes the user's disposition to care for planted cultures, keep the areas clean, enjoy the green landscape or, simply, to relax during his leisure hours. The user's psychic state can be at risk when it comes to wishing to park his own vehicle and when there is no parking space within the courtyard, or someone else is using it. The consequences of the reduction of space for traffic access and leisure within the courtyard can have an effect on the owner's feelings and his quality of life. This is also coupled with the feeling of health, without chemical analyses, as this is not the subject of this research. Garden tools (shovels, picks, forks, hoes, rakes and other), machines (motocultivators, lawn mowers, circular saws and other), equipment (protective clothing and footwear, pesticides, pumps, wheelbarrows and other), are used for cultivation, arrangement and maintenance of courtyards and are kept in the storage space, which does not belong to the elements of the courtyard, but to the element of supplementary construction. The starting point for determination of the courtyard size is the ratio of optimal dimensions which should be further consolidated. The aim is to determine the planned dimensions of creative solutions, avoid pathogenic positions of plants, as well as to establish the modalities and the relationships between the terms of construction and landscape arrangements.

\section{Method}

In courtyard arrangement, the methods of analysis, synthesis, as well as the empirical method, were applied and their procedures were carried out in accordance with the goal set. The case of landscape plans was chosen as a sample for arrangement of the rear part of a family house courtyard in the territory of the USA. The landscape plans are prepared by landscape architects and further individually elaborated in groups for the seasons of spring and summer [5]. The landscape plans of different plants and construction arrangements were analysed, namely for 10 courtyard locations, with their appearance in spring and 28 courtyard locations with their appearance in summer. The analysis includes the processing of the landscape plans, individual measurements and data characteristics: width, length and surface areas of the said locations. The synthesis of the said data is the illustration of the middle, the smallest and the largest measures, as well as the calculation of the average for the associated surface areas and the characteristics of their features. Certain figure contents and the properties of the total number of locations are perceived as a sample of unique surfaces of different dimensions of elements of arrangements for leisure.

The empirical method for determination of unfavourable plant positions was applied. In our case, the soil is red soil, of a minimal depth of 1 metre, in plantations of several types of fruit trees, vine, olive trees and kiwi pergolas. Supply of seedlings, excavation of holes, fertilisation, filling the holes, fixings for support, adequate treatment with pesticides and the time of growth up to first fruit is at least one year and all of that has its price. The smallest price is paid if the plant grows and bears fruit, but the biggest price is paid if it dies and we do not know the reason why. Certain positions in the courtyard soil are not suitable for plant life, as they are exposed to radiation which has a harmful effect on their growth and, in time, they die or have their growth stunted. The radiation which has a harmful effect on plants is pathogenic and, using rods, this can be detected by persons who practise radiesthesia or sensitive persons.

The illustration of rods has been given (Fig. 2a). One type of rods is galvanized wires $\varnothing 2,5 \mathrm{~mm}, 30 \mathrm{~cm}$ long and they are bent vertically at a length of $10 \mathrm{~cm}$. By means of the said rods, the position of pathogenic radiation in the terrain can be precisely determined. The method of application is as follows: while walking or standing, a sensitive person holds the rods with his/her fingers in front of him/her, loosely, parallelly, without hands touching each other, in the manner that the longer side is positioned at a slight slant towards the ground. In the location of pathogenic radiation, the rods will horizontally move left and right, or will cross in the shape of an $\mathrm{x}$ (Fig. $2 b)$ and, in the locations where such radiation does not exist, they will remain in a parallel position (Fig. 2c). There are a considerable number of publications on pathogenic radiation and some of them can be found in literature [6].

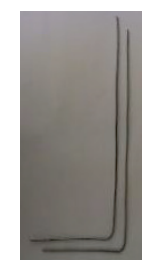

a)

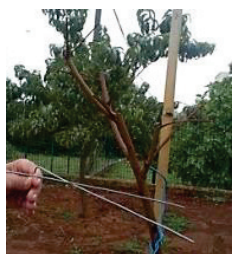

b)

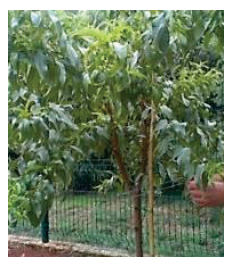

c)
Figure 2 Illustration and application of rods: photos by A. Poropat, Poreč-Špadići (24.08.2016); a) rods; b) pathogenic radiation; c) absence of pathogenic radiation

Modality is a method in which something happens or is reflected upon [7]. The terms of buildings and landscape arrangements in the family house courtyards are observed. The terms of building and plant arrangements are the names of ground level contents and methods of arrangement from the aspect of their modalities. Plants or trees which are harmful to the respiratory system (ambrosia and similar) are not cultivated or planted in courtyards. The processing of the terms of the said arrangements encompasses illustrations by means of figures and photographs, through the identification of titles (names) and characteristics (features), as well as modalities of arrangement (materials and dimensions), functionality (purposefulness) and position (where it is situated). Figures/photographs of 
some courtyard terms of landscape and building arrangements are analysed on the basis of choice from publications and the author's photographs. The synthesis is edited data of the said illustrations in the form of numerical ratios of the terms of building and landscape arrangements.

\section{Method of sustainable courtyard arrangement}

The results of the research on family house courtyards for the initially set aim are illustrated below. Courtyards can be without fences, thus being considered as incomplete and, in the same way, a family house without a courtyard is considered as incomplete.

\subsection{Planned dimensions of creative solutions for courtyards within the elements of arrangements for leisure}

Creative solutions were implemented in a considerable number of locations of landscape plans for family house courtyards, especially for the elements of arrangements for leisure in the territory of eight USA regions. The method of elaboration of landscape plans includes: drawing of lines, use of patterns and shapes, understanding the difference between fine and rough, creating of colours and contrasts, use of pattern rhythm, balancing and content, as well as measures and proportions. The selection of plants is important, such as the choice of trees, bushes, grassed surface areas, climbing plants and the charm of flowers. Allocation of creative solutions of certain locations is for children's play, natural herbage, vegetables, fruit, swimming pools, low bushes, garden flowers, outdoor life and attraction [5]. Each of the listed allocations of creative solutions also contains associated constructions and landscape arrangements and, as an example of unique surface areas, can visually be presented both in a plan (Fig. 3) and as a perspective (Fig. 4).

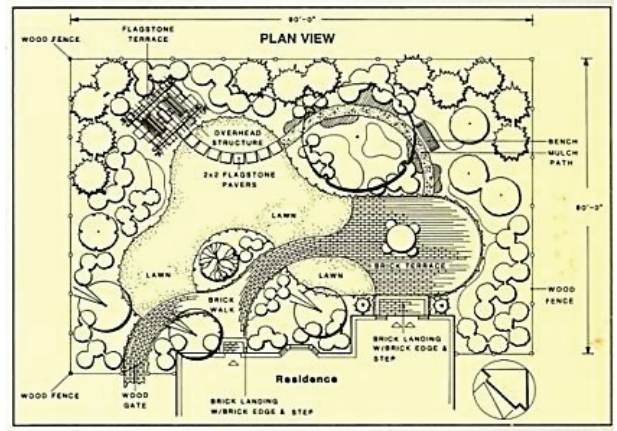

Figure 3 Landscape Plan L267 shown in spring, designed by Tom Nordloh [5]

Unique surface area processing is the result of the survey and account of data for dimensions of the elements of arrangements for leisure. The survey of the planned elements of arrangements for leisure in 10 locations shows that the smallest width is 18 metres and the largest 40 metres and that the lengths are somewhat shorter, the shortest being 14 metres and the largest 24 metres. Average surface area dimensions are: the smallest $251 \mathrm{~m}^{2}$, the largest $965 \mathrm{~m}^{2}$ and their average is $529 \mathrm{~m}^{2}$. The survey of the planned elements of arrangements for leisure in 28 locations shows that the smallest width is $6 \mathrm{~m}$ and the largest $43 \mathrm{~m}$ and that the lengths are somewhat shorter, the shortest being $7 \mathrm{~m}$ and the largest $29 \mathrm{~m}$. The average dimension surface area-wise is $418 \mathrm{~m}^{2}$, the smallest $45 \mathrm{~m}^{2}$ and the largest 1,249 $\mathrm{m}^{2}$ (Tab. 1).

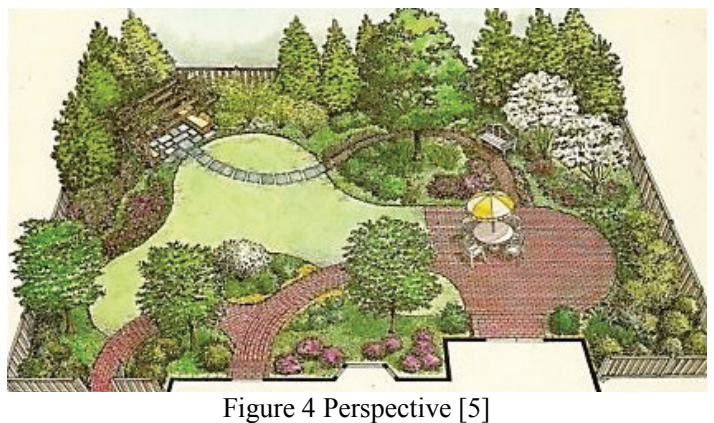

Table 1 Survey of ground dimensions within the landscape plans for the rear part of the courtyard

\begin{tabular}{|c|c|c|c|c|}
\hline & \multicolumn{4}{|c|}{$\begin{array}{l}\text { Planned dimensions of elements of arrangements } \\
\text { for leisure }\end{array}$} \\
\hline & Survey & Width / m & $\begin{array}{c}\text { Length / } \\
\mathrm{m}\end{array}$ & $\begin{array}{l}\text { Surface area / } \\
\mathrm{m}^{2}\end{array}$ \\
\hline \multirow{3}{*}{ 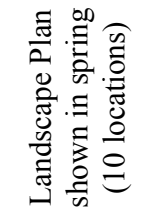 } & Average & 29 & 18 & 529 \\
\hline & Smallest & 18 & 14 & 251 \\
\hline & Largest & 40 & 24 & 965 \\
\hline \multirow{3}{*}{ 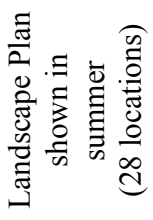 } & Average & 25 & 16 & 418 \\
\hline & Smallest & 6 & 7 & 45 \\
\hline & Largest & 43 & 29 & 1,249 \\
\hline
\end{tabular}

Surveys of two groups of landscape plans have been determined. The smaller group consists of landscape plans with their appearance in spring and they have an average surface area of the said element by $111 \mathrm{~m}^{2}$ bigger than the landscape plans with their appearance in summer. For the sake of comparison, the larger group of landscape plans with their appearance in summer has a surface area which is $132 \mathrm{~m}^{2}$ bigger than the optimal dimensions of the elements of arrangements for leisure [2]. Practically, landscape plans have elements of arrangements for leisure between 132 and $243 \mathrm{~m}^{2}$ larger than the surface areas of the optimal dimensions of the elements of arrangements for leisure [2]. If we apply the criteria for optimisation of elements of basic construction from Eq. (1) using the largest measurements $(246 / 0,34)$, then the optimal dimension of the building plot is $724 \mathrm{~m}^{2}$ and the dimension of the acceptable element of arrangement for leisure is $355 \mathrm{~m}^{2}$. The data differences between the dimensions of acceptable elements and landscape plan elements are then somewhat smaller, $63 \div 179 \mathrm{~m}^{2}$. The quoted data points to the fact that landscape plans refer rather to larger courtyards' surface areas as opposed to the surface areas of optimal elements. Landscape plans are creative, appealing to users, giving them a larger surface area for motivation, choice of purpose, feeling of 
enjoyment, relaxation or, simply, rest, by which their dimension for sustainable arrangement is consolidated.

\subsection{Unfavourable plant position with reference to certain seedlings}

In the group of seedlings consisting of peaches and nectarines, planted at a regular distance between them of 3 metres, one of the positions in the series of other positions is unfavourable for the growth of seedlings. One peach seedling was planted in 2006 (Fig. 5a), but it started visibly wilting after three years, in 2009 (to the left of it, parents and children are playing) (Fig. 5b). After it was taken out, a seedling of nectarine was planted in the same place, which had the same fate; it died in 2013. In the same year, a 1,5 metre-wide and 1 metre-deep hole was dug in its place which was left open for one year. At the end of the year 2014, a seedling of nectarine was planted again, but, after nine months, it rapidly grew and then wilted (in 2015), (Fig. 5c).

The reason for the situation of unfavourable position of plants was puzzling. Maybe nematodes were in question (earthworms and similar) and the wilted seedlings were without developed roots. I studied literature about pathogenic radiation [6] on the Internet and made the rods, which I applied for soil detection in the locations of the seedlings which had died. In the said unfavourable soil position, the rods moved to the left and right.

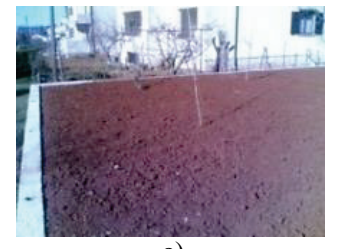

a)

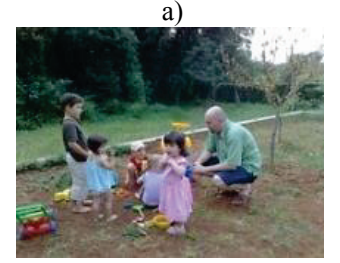

b)

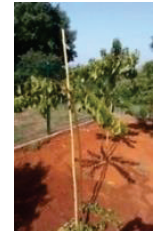

c)

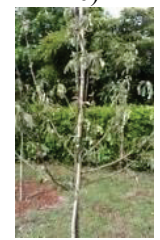

d)
Figure 5 Unfavourable positions of plants: photos by A. Poropat, PorečŠpadići, a) peach seedling (11.02. 2006); b) wilted (24.05.2009); c) wilted nectarine seedling (8.07.2015); d) wilted apple seedling $(23.05 .2015)$

In other peach seedlings of nice and healthy growth, the rods remained still and parallel. To check, the procedure was carried out also on other plants which were stunted or dead. The soil position in the location where an apple seedling was planted was also unfavourable, as, after two years of slow growth, it died in 2015 (Fig. 5d), following which it was pulled out. Application of the rods detected an unfavourable soil position in the location of the pulled out apple seedling (Jonathan apple clone). Other detected cases of unfavourable soil positions were found in the locations of stunted growth of vines. In one vine (Afus Ali vine clone), all larger branches wilted and one smaller one, looking healthy, is protruding as a sprout (Fig. 6a). In comparison to the others in a row, the second vine is dwarfish and of a poor growth (Fig. 6c). Both are pulled out. Stunted growth is particularly noted in the kiwi plant, whose main branch is dry in the middle of its width. It is 8 years old and its seedling is vertical, spiral and its crop non-existent or hardly noticeable (Fig. 6d). A dead olive tree joins these plants (Fig. 6b). Unfavourable soil position in a courtyard is at specific distances of between 2 and 5 metres and the diameter of the pathogenic radiation is between 30 and $50 \mathrm{~cm}$, in some positions even larger. There are also areas of unfavourable soil position several metres long and wide as per the mentioned diameter. For the sustainable growth of seedlings, it is important to move them away at least 50 $\mathrm{cm}$ from the positions of pathogenic radiation. It can be concluded that the rods have become a reliable tool for detection of unfavourable positions for perennial plant seedlings and its application can also be of use to enthusiasts of plant cultivation and fruits of the earth.

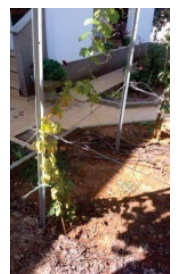

a)

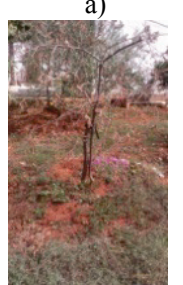

b)
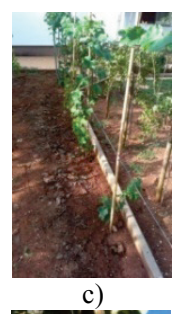

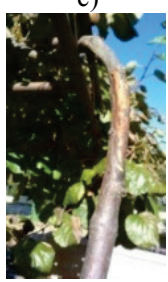

d)
Figure 6 Unfavourable positions of plants: photos by A. Poropat,PorečŠpadići, a) wilted half a seedling of vine (29.08.2015); c) poor growth of vine (24.06.2015); b) wilted olive tree (4.09.2015); d) half-dry kiwi tree (6.11.2015)

\subsection{Modalities and ratios in construction and landscape arrangement terms \\ 3.3.1 Term modalities in the content of courtyard construction arrangement}

Vehicular access. The vehicular access is open or transparent and adequately covered at the entrance portion of the courtyard and the solidly arranged ground surface is monolithic. The said access is a functional position for parking and conduct of the technological process in the traffic of personal vehicles, pedestrians, goods and services, between the street and house entrance. Its width can be with or without concrete kerbing and its length is measured from the street kerb or regulation line, including also the fence on the border of the building plot, to the entrance to the garage or the main open or covered entrance to the family house. On the left hand side (Fig. 7a), a vehicular access surface area is visible, where a car is parked. A smooth surface area is made of clinker tiles. The smooth surface is used to enable easier maintenance of cleanliness and for a more attractive appearance. The vehicular access side kerbs are low walls which protect the vehicular surface area from dispersal of the earth from its elevated position during rainy periods. The main vehicular entrance is the courtyard opening which is closed by a sliding gate. From the entrance door, the vehicular access is an irregular trapeze, which widens 
towards the garage entrance. The right hand side (Fig. 7b) shows the courtyard's open sliding gate and the vehicular access, on which a jeep vehicle is parked. The access surface area is rectangular, smooth and clad with stone tiles and the side kerbs are small walls.

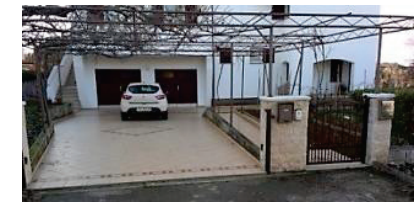

a)

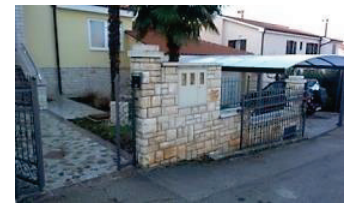

b)
Figure 7 Vehicular and pedestrian accesses in the courtyard: photos by A.Poropat, Poreč- Špadići (20.01.2016), a) the accesses are covered with a pergola; b) the vehicular access is covered with a canopy

Pedestrian access. The pedestrian access is open or transparent and adequately covered and the solidly arranged ground surface is monolithic. At the courtyard entrance part, the said access serves for conduct of the technological process in the traffic of pedestrians, goods and services, between the access street and house entrance. The pedestrian access width can be with or without concrete kerbing and its length is measured from the street kerb to the main open or covered entrance to the family house, also including the length of the associated outdoor stairs. On the right hand side (Fig. 7a), pedestrian access which, at the beginning, has outdoor stairs, can partially be seen and its extension is in the shape of the letter L and leads to the covered house entrance. A smooth access surface area was executed with clinker tiles with side parapets. On the other photograph (Fig. 7b) on the left hand side is the pedestrian access to the house. Venetian terrazzo was executed here, of a smooth surface, without parapets and it includes outdoor open stairs, with associated side parapets, as far as the house entrance.

Courtyard fence. The courtyard fence is one of the ways in which the surface area of the ground within the courtyard and the associated house can be identified, arranged and functionally protected. The fence can be solid, transparent or hedge, as well as their combinations, and is executed on the foundation base. A solid fence is metal, brick or concrete. For aesthetic reasons it can be a stone clad wall of specific thickness and height. In principle, for the Istrian region, the thickness of the fence is between 5 and $40 \mathrm{~cm}$ and up to one metre high. The fence measurements can also be larger and depend on the cultural heritage, tradition and terrain configuration and they are determined in keeping with the competent authority body provisions. A built fence can be made of stones, bricks or concrete blocks, separate or with associated fillings made of fence grills and, in some cases, metal or green and cut plant hedge. A hedge is a fence created of rows of closely planted shrubs or low trees, somewhat higher or lower than the aforementioned dimensions for solid fences. A portion of the solid fence is made up of posts (Fig.7a), clad in stone tiles and are a support for the courtyard gate and some of the pergola metal poles.

Fence niche. A fence niche is a courtyard wall which is, in one part, from the street side, indented for storage of waste disposal bins. Waste disposal bins are movable properties, so their identity is incorporated into the wall property. The said niche can be open or closed by a door and is used by the owner to store waste disposal bins (Fig. 8b). An open niche is an indent the size of a waste disposal bin (Fig. 8c) and is simple to use, both when loading or emptying waste disposal bins. In principle, waste disposal bins are kept in the public surface area at the side of a street (Fig. 10b), although this is not the best solution. Smaller garden waste disposal bins can also be found in larger courtyards. In most recent times, organised communal service companies have introduced individual waste disposal bins, which have become an accessory to courtyards and, as such, are left in the street.

Pergola. A pergola is a ground level transparent construction made of vertical and horizontal bearers, stiffened horizontally and vertically and having the purpose of being used by house occupants for rest, shade provided by plants such as climbing roses or flowers, as well as fruit plants such as kiwi, grapes and similar and, in some cases, it is used as a plant covered carport. The vertical bearers can be made of metal, reinforced concrete, wall poles or wood. Horizontal bearers can be wooden ledges, reinforced concrete posts, metal profiles or their combination, where plants branch out. What is more, some of those plants also bear fruit for food, leaves and fragrance and can serve as shelter for personal vehicles, as well as a courtyard decorative feature. They are also suitable for relaxation and socialising. Some of those constructions are made of metal piping, of 3 and 5 $\mathrm{cm}$ profile and the kiwi plant covers a considerable part of the pergola (Fig. 7a).

Access canopy. An access canopy is a ground level construction made of vertical and slanted or arch frame and a suitable covering, used for parking and as a shelter for personal vehicles at the entrance part of the courtyard. Frames can be made of metal, wood or reinforced concrete and, in some cases, the verticals are built posts. The cover can be made of hollow tiles, plastic, cane, sheet metal and similar. One of the access canopies shows its arched shape made of plastic (Fig. 7b). The vertical bearers are metal posts, which firmly hold the said canopy in a gentle arch with the elements of plastic for the purpose of sheltering a parked vehicle from the rain, snow or adverse weather conditions.

Distribution box. There is an imaginary vertical plane on the fence wall for the separation of the public and private property, making it a suitable place for installation of electricity and gas consumption meters and especially for installation of a hydrant, telephone and intercom, as well as letter boxes. As a rule, the installation of the said connections is not simultaneous and they are installed on fence walls or house walls, depending on the particular circumstances. The installation of a distribution box is functional in the way that it is publicly accessible for maintenance and reading of the quantity of consumed electricity or gas by the user and supplier, as well as for the use of a hydrant for fire protection. Distribution boxes for connection to electricity (Figs. 7b, 8c), and gas (Fig. 8a) are publicly accessible for the prescribed standard measures, height from the ground, as well as for the method of installation. On the fence wall (Fig. 8c) there are distribution boxes for connections to electricity, water and telephone, as well as a niche for waste disposal bins. The telephone distribution box can be either a pole or a distribution box, as a place for telephone connection (Fig. 
8d). There is a unit with connection to a hydrant (Fig. 8c) which can be seen in the middle, as a closed cupboard.
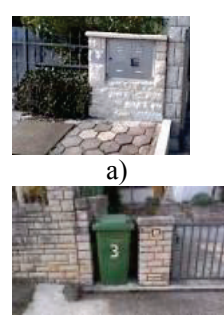

b)

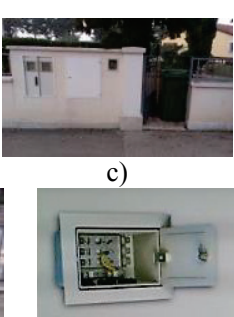

d)
Figure 8 Distribution boxes for gas, electricity, hydrant and telephone, photos by A. Poropat, Poreč - Špadići (28.01.2016)

Water manhole. A water hole is a basin with a lid with the purpose of a technological process of fluidity of water pipes and measurement of water consumption. The bottom left corner (Fig. 8a) is a metal water manhole lid. The said water manhole has sides made of reinforced concrete or wall material (bricks, stone and similar) in the shape of an underground chest, where a water meter is fitted. It is located on the surface, at ground level, or is elevated by the visible metal lid. The size of the underground manhole is publicly accessible (Internet) and standard. Its interior measurements are of width 1 metre and of equal length and the depth from the metal lid to the bottom is 1.1 metres. For the purposes of garden watering, next to the water manhole or in some other courtyard location, it is possible to also fit a tap for garden watering, which is visible to the right of the pedestrian access (Fig. $7 b)$.

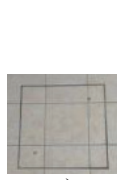

a)

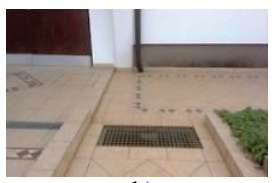

b)

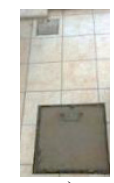

Figure 9 Cover lids on water and sewage shafts, photos by A. Poropat, Poreč-Špadići (28.01.2016)

Water collection tank. In the courtyard, the water collection tank resembles a basin which is imprinted into the soil and covered with a lid with the purpose of a technological process of pipes from which rainwater pours down and drains. The water basin can be made of concrete, with or without a groove. The groove at the bottom of the basin can be in the shape of an angle or a tbend and has a certain fall towards the water drain. The basin lid is made of concrete, at the level of the other tiles, so it is hardly visible and has two screws for its lifting. (Figure 9a). From the rainwater gutter (a vertical pipe) the water pours down to the basin fitted with a grill lid, so that, apart from the rainwater from the roof, it also collects the rainwater from the vehicular and pedestrian accesses and has an underground drainage pipe with the drainage outlet to the garden vegetation (Fig. 9b). Lids can be fitted on the box or shaft for electricity cables or the basin for insertion of rubber piping for watering of the garden (Fig. 9c).

Courtyard gates. Courtyard gates are vertical and mobile barriers on the fence wall, where traffic is directed for entrance and exit, for people, associated vehicles, services and goods. The door modalities are transparent or full, large or small, flat or rounded, metal or wooden and, in some cases, made of other adequate materials and can have sash or sliding opening. In principle, they are of standard shapes. Sash opening means that the door, on one side, leans on wall bearers (hooks) at the turning axis and, on the other side, there is a lock and a handle for its manual opening and closing. The left hand side (Figs. 10a and 10b) is a large metal and transparent door or gate and it has sash opening. The right hand side illustrates a small metal and transparent door or small gate, which equally has sash opening. Sliding doors (larger) open and close in the manner that they are fastened on the wall bearers and drivers, moving horizontally in the vertical position either automatically or by hand, closing or opening the space in the fencing wall (Fig. 7).

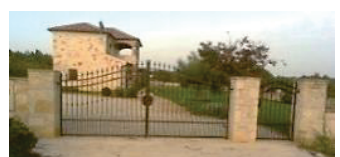

a)

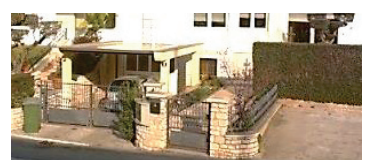

b)
Figure 10 Courtyard gate, photos by A. Poropat, a) courtyard gate Radići (18.09.2015); b) courtyard gate, Poreč-Čimižin, (26.01.2016)

Septic tank. A septic tank is a basin with the purpose of a technological process of waste waters which are released from toilets and associated sanitary units (wash basins, showers, bath tubs and similar) and accordingly settle down, purify and drain into drainage. It is used for houses which are not connected to the municipal sewage system, thus preventing the spread of foul smells and infections. The tank is a concrete underground room, consisting of two cells, each one with a lid. The waste waters are first released into a larger cell with $2 / 3$ of the capacity, where, from a special, smaller cell, using a compressor, fresh air is brought, which helps to decompose the contents, creating mud or sediment, as well as a clearer fluid, which spills over into a smaller cell, of $1 / 3$ of the capacity. The said sediment, when it fills the tank, is specially extracted and taken to another adequate location (processing, manure and similar) "Using advanced technologies of waste mud processing by composting, the mud can be applied in agriculture" [8]. From the smaller cell, from its highest point, fluid spills over into the draining part of the garden. The concrete basin for the process of purification is standardised and of minimal capacity of $10 \mathrm{~m}^{3}$ (Fig. 11). The septic tank can also be made of plastic or any other suitable material, but the dimensions are then considerably smaller.

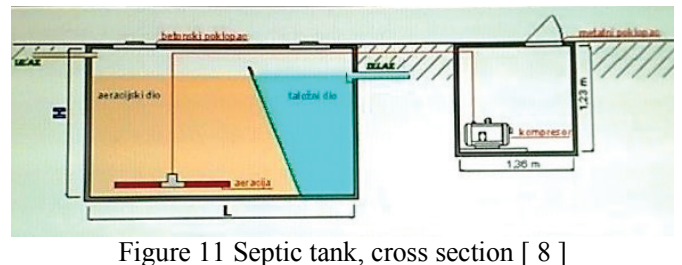

Garden fuel reservoir. A garden tank for storage of gas or liquid fuel is made of metal sheeting. Gas is butane, propane and similar and liquid fuels are naphtha, heating oil, mineral oil and similar. The gas tank is publicly accessible (Internet) and is of standard dimensions of varied shapes (oval, round and similar) and 
is installed above ground level, on a concrete base, with appropriate measures for protection and control of the permitted gas pressure. The liquid fuel tank has similar standards and protection measures and can be of oval, square or cylindrical shape, installed either above ground level or as an underground reservoir. Garden reservoirs have the purpose of a technological process of method of filling, storage and delivery of the liquid or gas fuel to the furnace for central heating and to the rooms of a house or a flat. One of the garden gas tanks (cylindrical) is fitted onto a concrete base between the fruit trees and the house, in such a way that it is masked from view (Fig. 12a). The second one is an oval garden liquid fuel tank, fitted above ground level and located on a corner of the courtyard (Fig. 12b).

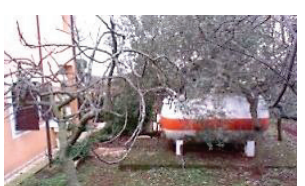

a)

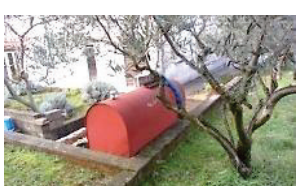

b)
Figure 12 Fuel storage tanks: photos by A. Poropat, a) gas tank, Kovači (09.02.2016.); b) oil tank, Poreč-Hospital (12.02.2016)

Garden water tank. A garden water tank is a water reservoir or reservoir for rainwater and a specific way of conduct of a technological process. The rainwater pours down from the roof and is carried away by horizontal gutters to the filter. In the filter (looks like a chest), it is filtered through a deposit of fine and rough sand and, filtered, drains into the impermeable concrete or brickbuilt room or closed space, which resembles an Istrian braided bottle "dumijana", which is not a floor space. The synonyms for a garden water tank are "cistern" "šterna", "gustijerna", "well" and similar, depending on the specific area's cultural heritage. On its upper side, it has a terrace and, in some cases, side walls and outdoor stairs and an overflow pipe, as well as an elevated opening or a gorge with a lid and a mechanism for intake of water. The said mechanism above the gorge consists of semi-circular metal rods, so that, on its highest part, there is a pulley with a chain and a suspended bucket. The bucket "šić" is manually, by means of the pulley chain, lowered vertically to the surface of the fluid, water is caught and vertically pulled out to the opening of the gorge. The said cistern serves for collection of the rainwater and is used for drinking, watering of the garden, washing and cleaning of the accesses, paths, vehicles and other. Water can be extracted from the cistern by means of a built-in water pump in the manner that the pump handle is manually driven up and down and the water pours out of its pipe or tap with the air pressure (Fig.13a). For the Istrian region, according to inspections on site, garden cisterns are installed in courtyards underground or halfdug in and are of general dimensions of between 15 and $100 \mathrm{~m}^{3}$, separated from or next to the family house. If there is no connection to the municipal water main, the stored rainwater in the garden water tank can be used for drinking and sanitary equipment (wash basin, sink, shower, toilet and similar), connected to water pipes and an electric motor pump for water extraction.

Garden well. Water well is a vertically drilled hole in the ground, on which mechanisms for water extraction and parts of concrete piping are built in, to a depth (approximately 15 metres) which enables extraction of underground water. In some parts, a source is a synonym for a well and, in others; a well is a synonym for a cisternwater tank. Underground water can be a natural water course or a layer of water in a sandy soil. The mechanism for water extraction is similar to the garden cistern one in landscape modalities. The well has the purpose of a technological process of collection and extraction of drinking water from the underground areas and, in some cases, also for connection to the house water system, cleaning, washing and similar (Fig. 13b).

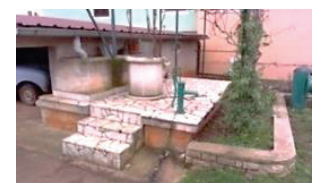

a)

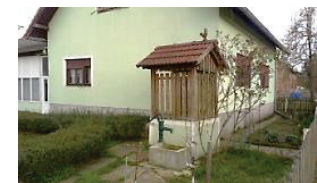

b)
Figure 13 Water tank and well: photos by A. Poropat: a) garden water cistern, Kovači, (09.02.2016); b) water well, Sigetac, Novska

$(26.03 .2016)[9]$

Garden path. A garden path is an oblong and narrowly arranged ground surface made of concrete, stone or tiles, which serves the user to maintain footwear cleanliness while moving around. The said path can be straight, curved, cascading, a small bridge or ramp with or without a parapet and can also have next to it a mat for removal of earth from footwear. There are numerous plan shapes of garden paths, one of which is a rectangular frame (Fig. 14a), which encompasses garden vegetation, consisting of a lawn and flower bushes and it can also be a path-wreath or a protective frame for protection from humidity, soiling and similar. A garden path can be made to suit all kinds of garden arrangements and especially arrangements to the swimming pool for sunbathing or terraces with benches for sitting (Fig. 14b).

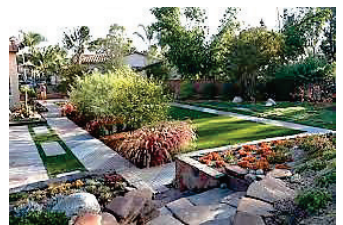

a)

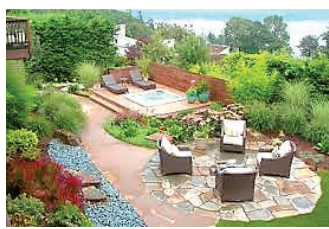

b)
Figure14 Garden path and terrace [10]

Garden terrace. A garden terrace is an arranged larger surface area made of concrete, stone or tiles, serving for the purpose of users' relaxation and recreation, fitted with suitable furniture consisting of chairs, table for socialising, dining and, in some cases, even loungers, armchairs and sunshades for relaxation. The said terrace can be used for gymnastics or recreation and, in some cases, for children's play. The continuation of the garden path is the terrace surface, which can be of a different plan shape and one of them has a semi-circular shape, made of Venetian terrazzo, on which there are four armchairs. In the background of the photograph, there is a raised plateau of the small swimming pool with two loungers (Fig. 14b). The garden terrace and the small swimming pool are surrounded by a landscaped garden.

Garden pond. A garden pond is a creatively shaped surface of a basin made of impermeable material 
(concrete, stone, clay and similar) containing stagnant water and can also be incorporated with paths and garden vegetation. There may be small animals in the water (fish, turtles and similar). For users, the said pond has the purpose of a pleasant view, attractive experience, walks and relaxation. An illustration of a garden pond is given below, visible water and garden path access, as well as of the surrounding paths with a small bridge and decorative plants (Fig. 15a).

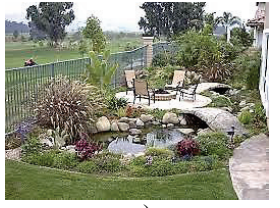

a)

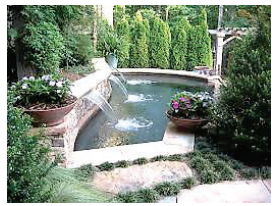

Figure 15 Garden pond and garden fountain [10]

Garden fountain. A garden fountain is a creatively shaped construction arrangement in the content of an aquarium with overflows and fountains of water into the basins; the same water circulates both spilling and being brought back and, in some cases, it is only stream water. The said fountain serves for users' enjoying the sight of it and a pleasant atmosphere. The rounded fountain basin is half full with water at the ground level. The said basin is made of concrete and stone, monolithic and bordered by stone, from which, from one side of the elevated wall, water pours out. On the fountain, there are two shallow round flower troughs and, around it, vegetation of lower and higher evergreen plants (Fig. 15b).

Garden box. A garden box is a ground level area, fenced off by a net, containing a small house serving for keeping house pets (dogs or other animals or birds) and their maintenance by the user. Keeping pets must not disturb the neighbours' peace by unpleasant barking or squeaking. If birds are in question (eagles, parrots and similar), then there is also protection on the top of the box. The floor is made of wooden planks and can also be made of stone or concrete. The house is small, wooden and has a roof with two slanting sides, for protection from rain and adverse weather and, with its shape and size, needs to be adapted for pets. The net is metal, transparent, with a door for limited movement of the said pets and at a height which would prevent pets from jumping over Fig. 16a.)

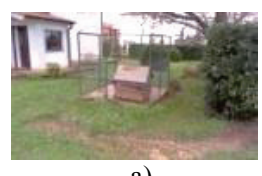

a)

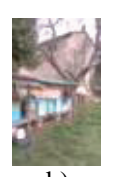

b)
Figure 16 Gardenbox and garden beehives, photos by A. Poropat, Dvori $(9.02 .2016)$

Garden beehives. Garden beehives are boxes made of wooden planks or some other suitable material, elevated from the ground level, for keeping bees, the technological process of making of honeycombs, as well as food for the users. It is possible to have garden beehives in courtyards; they are not recommended inside settlements but on the outskirts, which border with forests or agricultural areas (Fig. 16b).
Garden barbecue. A garden barbecue is a construction arrangement in the modality of the creation of volume and appearance and is made of built elements (stone, bricks and other) and binding composites (cement, lime, chamotte) or assembly parts, all needed for the furnace (concave arch) and barbecue, as well as the associated chimney for smoke extraction. The purpose of the said barbecue is to provide heat and enable grilling by the user and, in some cases, it serves as a place for gatherings, socialising and dining. An illustration of a garden barbecue is given and its associated terrace for sitting around and gathering of the users, as well as a covered pergola with its prop on the barbecue construction and the poles. On the side of the concave fireplace, there is a bay for storage of fuel (wood, coal, etc.). In the background of the barbecue, a swimming pool with loungers can be seen and, on the right hand side, the poles and a beam frame with climbing plants (Fig. 17a).

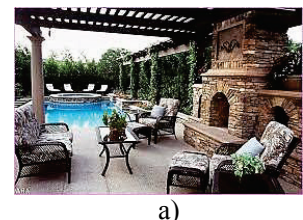

a)

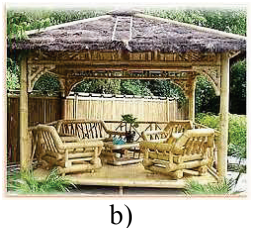

b)
Figure 17 Garden barbecue and garden pagoda [10]

Garden swimming pool. A garden swimming pool is a larger concrete basin, opened at the ground level, with a suitable entrance into it, and serves the purpose of clean water for the experience of looking at it, bathing, swimming and users' relaxation. The said basin can be coated with ceramic tiles, mosaic or other suitable material (plastic-prefabricated) and it has pipes for filling with clean water and at the bottom it also has a drainage vent for draining of the water. On the upper part the basin edges are terraced, smoothed and are used for loungers, sunshades and users' relaxation (Fig. 17a). If a garden swimming pool uses warm water, then the heating station is located within the family house. In the Istrian region, garden swimming pools are of small surface areas, i.e. between 20 and $100 \mathrm{~m}^{2}$ and of depth between 1 and 2 metres and they are used in summer.

Garden pagoda. A garden pagoda is a space with the purpose of sitting, relaxing and shade and it is constructed of stone poles, bricks or reinforced concrete, as well as a solid floor made of suitable materials, concrete, tiles and a covered roof construction made of Mediterranean roof tiles, raceways, metal sheet or straw. In order to be able to alter its position within the courtyard, the said garden pagoda can also be prefabricated, made of wooden poles, stringers, wooden plank floor for accommodation of armchairs and a small table, as well as a straw cover (Fig. 17b).

Garden protection. Garden protection is a kind of cover for arable soil for protection of plants in the garden and can be made of plastic or glass, or their combination. The function of the said protection refers to fierce sun or cold, as well as the adverse elements (hailstones, strong winds, frost, snow and similar), vermin (insects, flies, mites, wasps and similar), as well as vultures (birds, animals) and similar and all in order to obtain better crops and quality of the fruits of the earth. In some cases, plastic 
or glass greenhouses are heated with stoves in order to obtain the heat needed for the growth of seeds, cultivation and replanting of plants. The garden protections are of small dimensions so that they fit in with the courtyard and are used for the occupants' garden and not for commercial production. It is not good for the courtyard to have a large plastic or glass greenhouse which resembles commercial production (Fig.18a). An illustration is given of a smaller glass greenhouse in the combination of a metal frame, glass and plastic (Fig. 18b). The said greenhouse is of an appropriate size for a garden cover in the rear part of the courtyard.

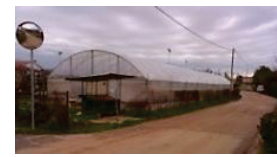

a)

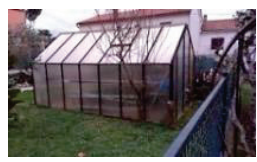

b)
Figure 18 Plastic and glass greenhouses: photos by A. Poropat, a) plastic greenhouse, Nova Vas (9.02.2016); b) glass greenhouse, PorečHospital (16.02.2016)

Courtyard parapets. The courtyard parapets are a solidly shaped mixture of a binding material (cement and/or lime water) and associated material (pebble, brick and similar) on the ground, built like a belt or concreted for the purposes of separating earth from or prevention of its spilling on to the solid base which is used for the said traffic of people and similar. In some places, parapets are used as an under-wall for the shaping of terrain that is slanting, inclining or in a depression (Fig. 19a).

Courtyard steps. Courtyard steps are solidly shaped material (concrete or reinforced concrete), made of stone, concrete or other suitable material in a terraced form for the purpose of climbing or descending of physical entities to specific heights. The said steps are outdoor steps in the courtyard, open, adapted to the configuration of the terrain (Fig. 19a) or for overcoming of ground heights. They can be single or double flight stairs, of standard dimensions of width and height of the tread (width +2 height $=63$ ) and the height of the handrail of $90 \mathrm{~cm}$, for access to the area in front of the entrance door. Their support on the ground is a wall or a stair flight of width of minimum $90 \mathrm{~cm}$ and, from the elevated end, the area in front of the house entrance (Fig. 19b).

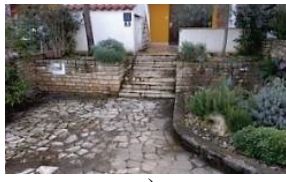

a)

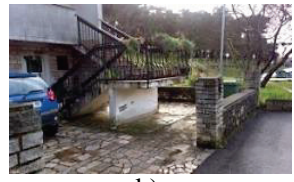

b)
Figure 19 Courtyard parapets and steps, a) steps, b) bifurcated steps, photos by A. Poropat, Poreč-Hospital (12.02.2016)

Flower troughs. A flower trough is a recipient for flowers, a luxurious vase or a stand for flowers and, in some cases, a flower embroidered curtain [7]. The said trough with single coloured or multi-coloured flowers serves as a decorative part of the courtyard for users and can also be a fixed feature on the ground or mobile, on the wall or any other suitable location. (Figs. $15 b$ and 22a).

Sculpture. A sculpture is an artefact which can be a figure of people, animals, birds, or a symbol of nature or something else, mobile or fixed, serving the purpose of decoration of the courtyard or a memory of or a souvenir from a loved person. The illustration of a sculpture is given of a nude woman, who is sitting on a stone and holding a tilted vase, as a symbol of the beauty of the appearance (Fig. 20b).

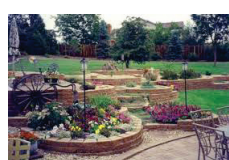

a

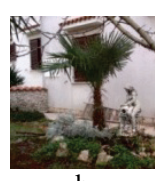

b
Figure 20 Garden lighting posts, flower troughs and sculpture: alighting posts [10]; b-sculpture, photos by A.Poropat (16.02.2016)

Garden light posts. Garden light posts are courtyard functional places for lighting, fitting of bird houses, flags and rows of vine on wire-linked posts and stakes, as well as for tying a washing line between the poles, for drying of the washing and similar. The said poles can be made of metal, wood, bamboo, or any other suitable material. There are multi-coloured flowers and, especially lighting poles, inside the semi-circular parapets (Fig. 20a).

Children's playground. A children's playground is a courtyard surface area, either multipurpose or arranged for installation of children's toys and other equipment for play. The said playground serves for children's play of volleyball, tennis, boules, mini golf, as well as for accommodation of swings, seesaws, merry-go-rounds, climbing-frames and similar. The illustration is given of children's playgrounds, which can be inside the courtyard, as well as outside it (Fig. 21a). Multipurpose means that other surface areas are also used for play, such as the vehicular access, which is covered by a pergola construction (Fig. 21b), the lawn or different parts of the garden (Fig. 5b).

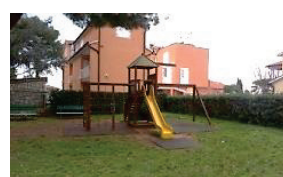

a)

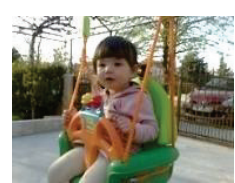

b)
Figure 21 Children's playground and swing, photos by A. Poropat, a) playground, Poreč-Hospital (16.02.2016); b) a little girl on a swing (12.04.2009)

\subsubsection{Term modalities in the content of courtyard landscape arrangement}

Garden flowers. Garden flowers are plants grown from seeds, tubers, bulbs, bushes, of low height and, in some cases, also climbing variety, with or without fragrance. The flower seeds are sown and, when sprouted, they are planted into the ground. The flowered plants, together with their leaves, are decorative parts of the garden, of attractive colours, sometimes fragrant, fresh and pleasant feeling for the users. With their surface area, the said flowers are incorporated into construction arrangements of parapets, terraces, lawns and associated garden paths. The flower colours can be various and the garden flower stems are mainly without thorns. Flowers, in combination of flower beds made up of pink and white clusters of low flowers, are interesting, looking like flower trough arrangements, which are flower 
embroidered areas in circles and pots and, next to them, there is associated bush-like greenery (Fig. 22a).

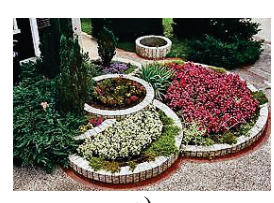

a)

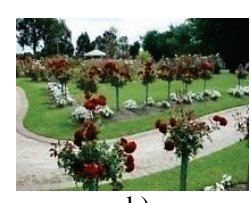

b)
Figure 22 Garden flowers and rose trees [11]

Generally speaking, plants contain flowers of different shapes, dimensions, colours and, in some cases, also fragrances. Garden flowers are used for "arrangement of windows, balconies and courtyards...and, in recent years, arrangement of town public surfaces has increasingly strongly and intensively been present" [12]. "The flower production is small and most of the needs are met by import, despite favourable climatic conditions for their production" [13]. Out of all flowers, we can particularly observe roses and other and we choose garden roses for the courtyard.

Garden roses. A garden rose is a tree or bush plant and has a root, from which develop one or several wooden stems with thorns and leaves made of small twigs, which, individually, contain between three and seven ribbed leaves of green colour, resembling fishbone and blades and have a flower at the top of the stem. Garden roses are planted in the ground and can be of various colours, with or without fragrance. They differ from other garden flowers by the fineness of the flowering and their sepals and perigone, composed of many rounded and larger petals which open in the shape of a bell. There are several flowers on a single tree stem and they resemble a bouquet (Fig. 22b). Next to the rose trees, there are clusters of white flowers and the surrounding lawn (a surface of cut grass) and a garden path.

Vegetable patch. A vegetable patch is an arable surface area of soil, where vegetables which contain nutritious crops and/or plant leaves, and sometimes seasoning herbs, too, used for food, are sown and planted. In principle, vegetables are annual plants, like for example lettuce, tomatoes, radishes, onions, garlic, potatoes and similar. They are cultivated on the surface of the garden, in several rows and with difference in varieties of vegetables and seasoning herbs and are separated from other areas of the garden by kerbs or parapets and, in some cases, without them, bordering only a lawn or ground. Seasoning herbs are aromatic and are grown in low bushes. They have small flowers of the same colour, which can have either different shades or individually be of different colours (parsley, celeriac, oregano, thyme, sage, etc.). An example of a vegetable patch with plants of tomatoes, lettuce and parsley (Fig. 23a).

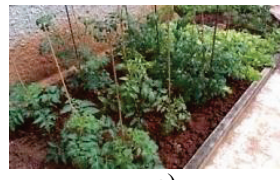

a)

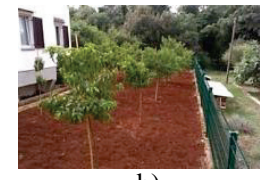

b)
Figure 23 Vegetable patch and garden orchard: photos by A. Poropat, Poreč-Špadići, a) vegetable patch (23.05.2015); b) orchard (19.07.2015)
Garden orchard. A garden orchard is an arable surface area of soil, where perennial fruit trees are planted at a distance and separation (kerbs, metal fencing, hedge, etc.). The fruits are used for consumption, as food. Following their planting, the fruit trees are then pruned and maintained by digging around them, ploughing, fertilisation and protection by pesticides and netting. An illustration is given of a peach orchard with young peach trees and the method of soil cultivation, as well as protection, consisting of a metal fence on one side and a parapet, leading to the garden path, on the other side (Fig. 23b).

Evergreen vegetation. Evergreen vegetation occupies a surface area in the courtyard, planted with plants which stay green all year round. The said plants can be low or tall and serve as an attractive feature, pleasant to the eye. It is maintained by nurturing of its branches, twigs and leafage. The low plants are of a dwarf variety and perennial and the tall ones are cared for naturally or are trimmed, to resemble different geometrical shapes (cylinders, cones, spheres and other), and, in some cases, umbrellas, haystacks and similar (Fig. 24a, 24b).

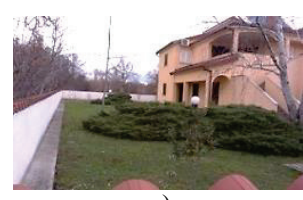

a)

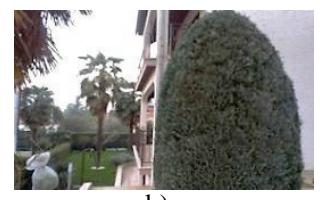

b)
Figure 24 Evergreen plants: photos by A. Poropat, Poreč-Špadići

(24.08.2016), a) low evergreen plants, b) high evergreen plants

Courtyard trees. Courtyard trees are individual plantings of perennial plants which have densely developed branches in the courtyard, such as fruit trees of Sharon fruit, cherry and similar (Fig. 25a), mandarin orange (Fig. 25b) and other, pears (Fig. 26a), or they can be without fruit, such as a flowering tree of mimosas, camellias, lime trees and similar. The said fruit trees are used for food and those which do not bear fruit for attraction of their appearance and in some cases also for their fragrance.

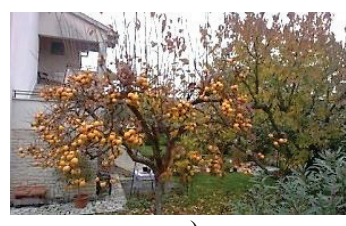

a)

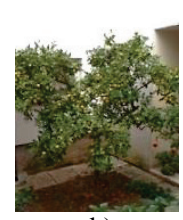

b)
Figure 25 Courtyard trees, photos by A. Poropat, Poreč-Špadići (02.10.2015), a) Sharon fruit, b) mandarin orange

Garden lawn. A garden lawn is a grassy ground surface area in the courtyard. It is sown, fertilised and cut, so that it looks like a carpet, serving for the appeal of its appearance, look, sense and pleasant smell for relaxation and for fun activities by children and adults. Its cutting can be manual, with a lawn mower, or, with the latest invention, a small battery-operated robot. There can be found trunks for sitting and a fruit tree or two, as well as some flowers (Fig. 25a). 
Garden compost. Garden compost is artificial organic manure, made of all sorts of rotted waste of vegetable, mineral and animal origin, or their mixture [14]. It is created by cutting of garden plants and storing it into a recipient (crate), with appropriate treatment for use as fertiliser for eco production. The said compost container can be a wooden, concrete or plastic container, positioned above ground level or underground, with its upper part at the ground level. An illustration of a smaller garden compost container is given, made of metal posts and wooden partitions, where compost is stored and it is processed by worms (Fig. 26b).

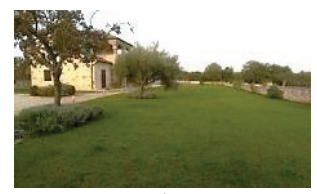

a)

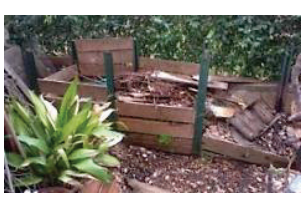

b)
Figure 26 Garden lawn and compost, photos by A. Poropat, a) lawn, Radići (18.09.2015); b) compost, Poreč-Finida (17.02.2016)

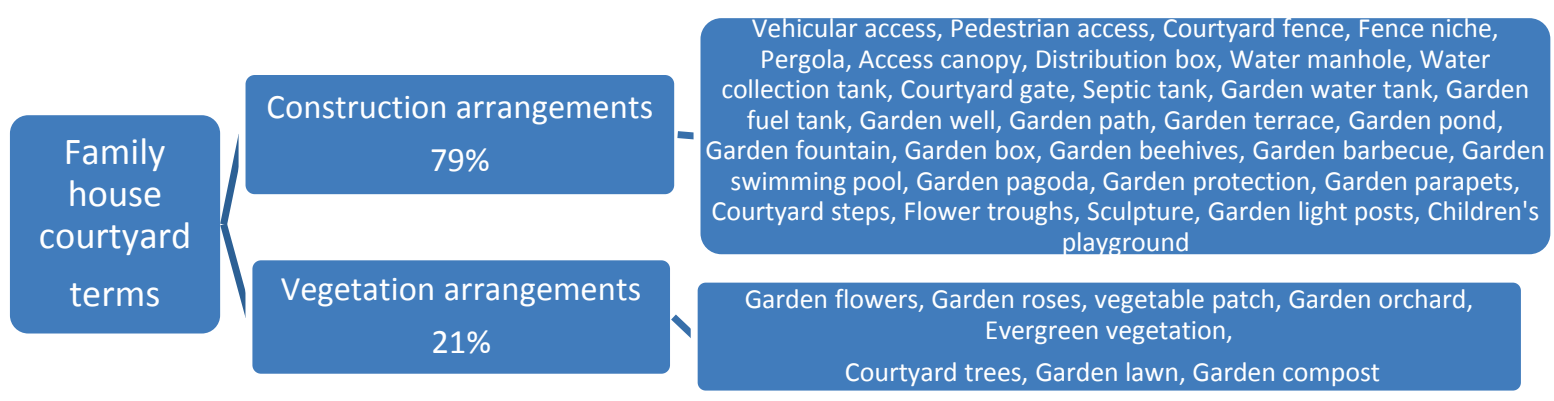

Figure 27 Illustration of family house courtyard terms

\subsubsection{Ratio of construction and landscape arrangement terms}

In the family house courtyard, new structural rules have been determined, which are unambiguously identified by the construction and vegetation arrangements and, terminology-wise, differ from construction, building and their reconstruction, as is determined in the terminology glossary of the Construction Law from 2013 [15]. This is the reason why the terminology glossary of the said Law needs to be supplemented and harmonised with the new courtyard terms. 38 terms have been identified of possible contents in a courtyard, of which $79 \%$ refer to construction arrangements and $21 \%$ to vegetation arrangements (Fig. 27). The said terms are suitable for use by the owner, in the manner that he/she realises them by the quantity and number of names, according to his/her interest and will and in accordance with the size of the courtyard available. The exceptions to the will of the owner are the terms whose application may be subject to respecting certain standards, fire protection measures, avoiding planting certain species which are harmless for the respiratory system, as well as to keeping pets which disturb the neighbours with their barking or screeching of birds.

\section{Conclusions}

Based on the afore-determined facts from the research results, the following conclusions are possible:

Landscape plans for the rear part of the courtyard are rather suited for larger surface areas than the determined optimal dimensions for the Istrian region. In the courtyard, there is landscape architects' creative work, attractive to the owner's will regarding the choice of its use, the feeling of enjoyment, relaxation and rest and, especially recreation, with which their size for sustainable arrangement is consolidated.

Prior to planting perennials, especially fruit trees, olive trees and vine pergolas, it is necessary to carry out the detection of the soil in the family house courtyard by a dowser, or using rods, if you happen to be a sensitive person.

By soil detection, the precise positions which are unfavourable for the growing of the aforementioned seedlings in the courtyard can be determined, as they would be affected by pathogenic radiation. Moving the seedling by just a short distance $(50 \mathrm{~cm})$ from the determined radiation guarantees its healthy sustainability and a generous crop, provided it has proper feeding and treatment.

A family house arrangement consists of its construction and vegetation parts. The ground surface areas containing vehicular and pedestrian accesses are terms of construction arrangement of access or approach and belong to the element of arrangement of traffic access. The other construction and vegetation arrangements are the terms contained in courtyards and their plan surfaces belong to the element of arrangement for leisure. Certain contents of the courtyard have the characteristics of sustainable term and associated relations, as well as the modalities of creativity, performed and conducted by the occupants or ordered for realisation by competent craftsmen, companies or landscape architects. The said construction of the courtyard should, terminology-wise, be separated from other constructions and buildings.

Construction arrangements are artificially and monolithically shaped construction materials, as firmly linked parts of the ground surface, consisting of either parts or a unity of specific terms up to the ground level and differ in their positions, shapes and sizes, according to the courtyard users' desires and, in some cases, to particular technological processes or certain measures of protection and specificities of terms.

Landscaping arrangements are either artificially or naturally grown plants, firmly ingrown on fertile soil, individually or in specific term clusters and differ in their positions, species, colour, fragrance, appearance and size, 
all in accordance with the courtyard users' desires and, in some cases, also with the measures of protection.

38 possible terms have been determined for the method of sustainable arrangement of a family house courtyard, of which $79 \%$ refer to construction arrangements and $21 \%$ of terms to vegetation arrangements. The application of certain terms within the surface area of the associated courtyard, as well as the choice of several of them, is in accordance with the owner's interest and will.

The results of the research on methods of sustainable arrangement of a family house courtyard, as well as the formulated conclusions, are the solution for the introductory set goal.

This article is intended for scientists, architects, competent government authorities and users of courtyards.

\section{Acknowledgement}

This article completes the scientific and research topic of "Seljačka obiteljska gospodarstva $u$ Istri" (01470103) (Peasant family farms in Istria) by the authorised Ministry of Science and is financed from funds realised at the Poreč Institute of Agriculture and Tourism from its projects.

\section{Reference}

[1] Poropat, A. Prostorni činitelji izgrađivanja parcele obiteljskih građevina na primjeru zapadne obale Istre. // Prostor. 11, 2(26)(2003), p. 227.

[2] Poropat, A. Optimization model for family house plot elements-the Istria case. // Tehnicki vjesnik-Technical Gazette. 20, 1(2014), pp. 199-205.

[3] Poropat, A. Prilog pojmovnom i metodološkom pristupu mjerama kućišta - rezultati istraživanja. // Međunarodni kongres Energija i okoliš 2000. / XVII. Znanstveni skup o energiji i zaštiti okoliša, Opatija 2000, 1, pp. 291-307.

[4] Poropat, A. Prostorni činitelji izgrađivanja parcele obiteljskih građevina na primjeru zapadne obale Istre, Doktorska disertacija, Zagreb, 2002.

[5] Scott, D.; Opisso, M. J.; Poplawski, D.; Nordloh, T.; Morgan, J. TheBackyard Landscaper, 40 Professional Designs For Do-It-Yourselfers. // Home Planners, Inc, 1992.

[6] Galić, I. Radiestezija zaštita od štetnih zračenja, Založba Mladinska knjiga, Ljubljana-Zagreb, 1990.

[7] Klaić, B. Rječnik stranih riječi A-Ž, Nakladni zavod Matice hrvatske, 1985.

[8] Septička jama, https://www.google.hr/webhp?sourceid= chrome-instant\&ion $=1 \&$ espv $=2 \&$ ie $=\mathrm{UTF}-8 \# \mathrm{q}=$ septi\%C4\%8Dka\%20jama (18.02.2016)

[9] Zdenac, https://www.google.hr/search?q=zdenac\&espv= $2 \&$ biw $=1920 \&$ bih $=955 \&$ source $=1 \mathrm{nms} \&$ tbm $=i$ isch $\&$ sa $=X \& v$ ed=0ahUKEwjpj4a2h4HLAhWF2CwKHZcnDgYQ_AUIBi gB (18.02.2016)

[10] The backyard ladscape, https://www.google.hr/ webhp? sourceid $=$ chrome-instant $\&$ ion $=1 \&$ espv $=2 \&$ ie $=\mathrm{UTF}$ $8 \# \mathrm{q}=$ the+backyard+ladscape $(18.02 .2016)$

[11] Cvijetnjak i ruže stablašice, https://www.google.hr/ webhp? sourceid $=$ chrome-instant $\&$ ion $=1 \&$ espv $=2 \&$ ie $=$ UTF-8\#q=cvjetnjak $(18.02 .2016)$

[12] Geršak, D. Jednogodišnje cvijeće u javnim nasadima Međimurja - odabir bilja. // Agronomski glasnik. 67, 24(2005), pp. 285-288.
[13] Horvat, D.; Jerčinović, S.; Židovec, V. Cvjetne vrste za izradu suhih aranžmana - potrebe i dostupnost sjemena. // Sjemenarstvo. 28, 1-2(2011), pp. 53-66.

[14] Dvorski-Nekić, D. Ekološko zbrinjavanje aktivnog mulja prehrambene industrije. // Agronomski glasnik. 73, 6(2011), pp. 327-336.

[15] Određena točka članka 3. Zakon o gradnji. // Narodne novine, br. 153/13.

\section{Author's address}

Zsv. dr. sc. Amorino Poropat

Institute of Agriculture and Tourism of Poreč,

Karla Huguesa 8, 52440 Poreč, Croatia

Tel.: $+385(0) 52408302$

Fax: $+385(0) 52431695$

E-mail: amorino.poropat@gmail.com 